fear of the effect on the statistics by which the local education authority, knowing little of education, judges the efficiency of his school and his own fitness for promotion, or by which the employer, knowing even less, judges the suitability of individuals for purposes never contemplated by the examination authorities--there examinations are a very mischievous thing. Unless the habit of working and teaching for examinations before everything else is abjured, I see little hope of the type of education which alone can save democracy, and bring up a race of free men and women.

There are other reforms which are urgently needed, if our present system of education is to be brought nearer to the fulfilment of such an end. The prolonging of the time of education is obviously one, provided that the education is of the type which liberates and trains the mind, and does not merely rivet its fetters more tightly. A great reduction in the size of classes in most subjects is another; not necessarily in all subjects, or for all purposes; but such a reduction as will give the individual member of the class a chance, and will enable a teacher to encourage a pupil who has a line of his own to follow it up, and to see that every pupil is mentally active and not merely receptive. Young people have not indeed enough experience to prescribe or to conduct their own studies to the extent imagined by some enthusiasts; but they have minds which should not be allowed to be inert or be driven along precisely the same route as twenty-nine or thirty-nine other minds, and the smaller the class the less the risk of this.
The suggestions which I have made as regards educational practice have nothing new in them, but I have deliberately chosen familiar instances to illustrate my main contention. My object has been to assert that these are no matters merely of theory or of finance or of administrative or political convenience, but of vital and immediate urgency, if we are not unconsciously to bring up a race which, with its mind stunted, its capacity for freedom undeveloped, will be the easy prey of the politician, the journalist and the dictator; and that if a free democracy is to continue, we must educate for it, for in many respects our present educational system is better calculated to produce a servile and passive mentality than to elicit an activity of mind and an independence worthy of free men and women.

We have reached a point in the history of Western civilisation when the forces which make for the enslavement or the inertness of mind and spirit are active as they have not been for centuries. It is therefore incumbent upon us to test our educational institutions and methods at every point by their tendency to produce or to hinder freedom of mind, to cut out all that makes for the standardisation of individualities or is hostile to ultimate independence of judgment, at the same time so setting before the young the higher values, which make for good life and good citizenship, that they may have the chance of freely making them their own. If we can do this, we may yet see the development of a type of humanity richer in freedom, self-discipline, courage and vision than any which the world has yet known.

\title{
Recent Progress in the Study of Early Man*
}

\section{By Sir Arthur Smith Woodward, F.R.S.}

$\mathrm{W}^{\mathrm{n}}$ HEN meeting in East Anglia it is appropriate that the Section of Anthropology should devote special attention to prehistoric archæology. In this part of England so long ago as 1797, John Frere made the first scientific observations on palæolithic implements which he had dug out of a superficial deposit at Hoxne. During recent years, Mr. J. Reid Moir has excited wide interest by his discoveries of the oldest known stone implements, which he has collected with remarkable zeal and discussed with acute observation. Here also arose the 'Prehistoric Society of East Anglia', which has been so well supported

* From the presidential address to Section $\mathrm{H}$ (Anthropology) of the British Association delivered at Norwich on September 9. during its career of more than twenty years, that it has gradually widened its sphere until now it becomes the 'Prehistoric Society', devoted to advances in its subject in all parts of the world. We are, indeed, now confronted with problems much greater than those which the pioneers in western Europe dealt with, when they were laying the foundations of research in prehistory. Traces of men who lived before the dawn of history in widely separated parts of the earth's surface have been discovered in increasing abundance during recent years ; and a study which at first was more or less local has now become one of world-wide scope.

Among the several branches of science which contribute to our understanding of the subject, 
those of palæontology and geology are of considerable importance. The period of man's existence on the earth has been so short that there has been no appreciable evolution among the mammals associated with successive human races; but many migrations and extinctions are observable, so that these mammals can often be used for determining the relative ages of the isolated deposits in which human remains and implements occur. In some cases also the mammals are probably enough to show the nature of the climate and the local conditions under which they lived. The contemporary geological changes, though small, likewise help in explaining migrations and perhaps some extinctions ; while the peculiar circumstances of the Great Ice Age, under which early man flourished in the northern hemisphere, varied so much from time to time, that they have been used in forming a plausible chronology. As a palæontologist and a geologist, therefore, I propose to discuss some of the latest developments of prehistory.

It has long been recognised that the earliest men of which traces have been found in Europe did not originate on this continent, but were immigrants from some other region. It is thus important to examine the numerous associated mammals to ascertain whence they came; for most of these mammals seem also to have been immigrants to Europe just before or during the Pleistocene period when man began to live here, and they may give a clue to his origins.

Sir W. Boyd Dawkins was one of the first to take a broad view of the mammals which accompanied the successive races of early man in Europe, and he eventually published a map to illustrate their mixed origin. In addition to some which were already in the middle of the European continent, others seemed to have come south from the Arctic regions, others had passed directly west from the middle of Asia, while a few could only be explained as having come north from Africa over old land bridges to Gibraltar and southern Italy. These mammals might not all have lived together, but they at least showed how varied were the routes open to the movements of primitive men.

It now appears that the tracing of the warmer types of mammals to an African source was a mistake. Recent researches seem to have proved that during the Pleistocene period there was no direct communication between Europe and Africa, either through Gibraltar or through Sicily and Malta. Geologists are satisfied that certain shells which are characteristic of northern seas could not have entered the Mediterranean to be found there in Pleistocene sea beaches if the Straits of Gibraltar had not been open. Others have remarked that among the numerous remains of mammals which occur in some of the caves at
Gibraltar, there is nothing distinctly African. Dr. Raymond Vaufrey has more recently examined the fossil mammals and stone implements found in the caves and other Pleistocene deposits of Sicily and Malta, and he shows clearly that although these islands were connected with Italy at the time, they never had an extension to Africa.

The latest discoveries of fossil mammals in the caves of Palestine and Syria, as interpreted by Miss Dorothea M. A. Bate, show that during the early half of the Pleistocene period, Asia and north Africa were much more closely connected than they have been since. The country was comparatively well watered, with luxuriant vegetation and forests, and mammals could readily migrate both east and west. Even so characteristic an African animal as the wart-hog (Phacochorus) was then living in Palestine. The connexion of Asia with Africa was thus as definite as that with Europe; and the explanation of the partial identity between the Pleistocene mammals of Africa and Europe is probably that they had a common source in Asia, and diverged west in two different directions, one southwards, the other northwards.

This conclusion is supported especially by the apparent origin and former distribution of the spotted (or cave) hyæna, Hycena crocuta. In the Pliocene deposits of the Siwalik Hills in northern India, there are jaws and other remains of hyænas which are not quite $H$. crocuta, but may well represent its ancestors. By the Pleistocene period, the typical $H$. crocuta was already in existence in India, as shown by a tooth discovered in the Karnul caves, Madras. Remains of the same species have also been found in Pleistocene deposits in central Asia and even in China. They are likewise widely spread over Syria and northern Africa, where only the striped hyæna $(H$. striata) lives to-day. $H$. crocuta, therefore, is not an African animal. It originated in Asia, spread thence in different directions in the Old World, and has survived only in southern Africa, which is at one extremity of its former wide range.

It is also to be observed that none of the characteristically African antelopes occurs among the European Pleistocene fauna. Remains of the gazelle have been found, but this animal is as much Asiatic as African. The Saiga antelope and Nemorhoedus, which are Asiatic to-day, are the only other antelopes which reached Europe in Pleistocene times.

The Pleistocene mammals of Europe, therefore, show that when they flourished on this continent, the only direct land communication was through Asia. The earliest races of men must have reached western Europe by that route; and as a succession of stone implements, remarkably similar to that 
which is now so well known in Europe, has already been found with early Pleistocene faunas in Africa, it might at first be supposed that there were parallel migrations of the same men from the Asiatic to the African continent. Implements, like languages, however, afford no certain clue to the races which made and used them, and the same tools must have been invented independently more than once. It is therefore unfortunate that hitherto no human remains have been found in undoubted association with any of the earliest implements and Pleistocene mammals in Africa.

Two years ago a committee of geologists which met in Cambridge expressed itself as satisfied with evidence which Dr. L. S. B. Leakey submitted in order to prove that he had discovered modern types of human skull and lower jaw with very primitive implements and early Pleistocene mammals in Kenya Colony. In fact, it appeared as if the same types of implements in the same geological stage in Europe and Africa had been made by two distinct genera of men. Quite lately, however, Prof. P. G. H. Boswell, under the guidance of Dr. Leakey, has examined the geological formations in the region where the discoveries were said to have been made, and he is now convinced that there is no proof of the association which has been claimed. The human remains in question seem to have been obtained from disturbed deposits, and may have been buried at a comparatively recent date. With later types of stone implements and remains of modern mammals, the only satisfactory fragments of the human skeleton which have hitherto been found in Africa belong to the genus Homo. Many of the fossil forms are related to the surviving South African bushman, and if any of these passed directly from northern Africa into Spain, as has sometimes been supposed, they must already have learned to make rafts by which they could cross the Straits of Gibraltar.

The only fossil hitherto discovered in Africa, which suggests that that continent may have produced man, is the immature skull from a deposit of uncertain age (probably Pleistocene) at Taungs in Bechuanaland, which was named Australopithecus by Prof. Raymond A. Dart in 1925. It belongs to an ape, and seems to exhibit more human characters than the skull of any of the existing apes; but Prof. Dart's complete account of the fossil has unfortunately not yet been published.

The earliest known jaw of an ape, Propliopithecus, was discovered long ago in the Oligocene of Egypt, and numerous jaws of apes related to the existing chimpanzee are now being found in the Miocene of south-east Africa. Equally abundant, however, are the jaws of apes in the Mio-Pliocene deposits of northern India, and some of the teeth preserved in them exhibit a remarkable approach to those of man. I still think, indeed, that according to our present knowledge, the links which connected apes with man are most likely to be found in southcentral Asia. As the late Joseph Barrell pointed out, the east to west ridge of the Himalayan Mountains was gradually raised up at the time when northern India was covered with a great forest which swarmed with apes of many kinds. The formation of the ridge separated off a northern portion of the forest which became subject to comparatively inclement conditions. The apes stranded in this northern portion would be disturbed by the extensive destruction of the trees, and the survivors would be driven to be groundapes and change their habits of feeding. They would thus be modified in the direction of man.

These considerations, with the geographical distribution of the few oldest known remains of fossil man, led the late Dr. Davidson Black to make plans for a systematic examination of the later Tertiary deposits of south-central Asia. In 1925 he reviewed the whole subject in an important paper published by the Geological Society of China. In the summer of 1932 he actually traversed a route from eastern China, through northern India, to Syria and the western coast. Dr. Black, unfortunately, did not live to see the realisation of his project, but we are glad to learn that Father P. Teilhard de Chardin will take his place in researches beginning in India this autumn.

It is very interesting to notice that if central Asia was actually the region in which the human family originated, the few known fragments of the oldest fossil men are distributed geographically just as a palæontologist would expect them to be. The late Dr. W. D. Matthew pointed out that if each race of animals evolved at a single centre, a succession of waves of increasingly advanced genera must have radiated outwards from that centre. The latest and highest types would be found at the actual place of evolution, and they would be surrounded by rings of less advanced types of lower and lower degree until the lowest would occur at the outer limit.

The fragments of the oldest fossil men hitherto discovered are indeed very few, but although allowance for negative evidence may cause some hesitation, it is at least noteworthy that they are all on the periphery of the Euro-Asiatic continental area. Eoanthropus and Heidelberg man were found on the western margin of Europe, Pithecanthropus at the southern margin of Asia, and Sinanthropus close to the eastern coast of Asia. If human types were evolving near central Asia, the places of these actual discoveries are in a distant partial ring round the source. 
The next stage in man's development is much better known, because by this time he had learned to bury his dead in security. As examples have been found in caves so far apart as France and Palestine, burial had doubtless become a general custom. Many whole skeletons are therefore available for study.

This stage is that of Neanderthal or Mousterian man, which is geologically the latest to retain several specially ape-like characters associated in a single individual. Its Asiatic origin is now still clearer to a palæontologist than that of earlier man. Burials in caves which seem to be approximately of the same date reveal a comparatively high Neanderthal type in Palestine, a low and bestial type in western Europe. On Matthew's principle already mentioned, the first is therefore nearest to the original source. The accompanying stone implements support this conclusion, for whereas in western Europe the implements are merely trimmed broad flakes, in Palestine there are also many narrow blades which resemble those made by later (Aurignacian) man in Europe. The Asiatic type of Neanderthal man was indeed progressing in skill to meet his increasing needs. He appears to show us modern man in the making.

Until typical Homo sapiens had come into being, man's only outlet from Asia seems to have been by land in the direction of Europe and Africa. As soon, however, as he had attained this final stage of development he must have been able to construct rafts or boats, by which he crossed the narrow seas of the East Indies to Australia, and perhaps the equally narrow seas at Bering Straits to North America.

Australia is shown by its past and present animal life to have been separated by sea from the rest of the world during the whole of the Tertiary era, including Pleistocene times, and it was isolated too early to be inhabited by the ancestors of the apes. Man is therefore certainly an immigrant from overseas, and we know that he reached the country when various relatively large Pleistocene marsupials were still living there, because a fossil human skull has been found at Talgai in Queensland directly associated with their remains. This skull is essentially the same as that of the existing Australian aborigines, who have retained a mode of life like that of the latest Palæolithic hunters of the mainland.

It is remarkable that very few traces of men who might be related to the ancestors of the Australians have hitherto been recognised in their homeland in Asia. The skulls of Homo wadjakensis from an old lake deposit at Wadjak in Java, discovered and described by Dr. Eugene Dubois, may perhaps be placed among them. The skulls named Homo (Javanthropus) soloensis, more recently discovered by Dr. W. F. F. Oppenoorth in an old deposit near the Solo river in Java, seem to be intermediate between the skulls of Pithecanthropus and the modern Australian, though they have not yet been described in detail. As many have observed, the skull of Rhodesian man (Homo rhodesiensis), from a cave in northern Rhodesia, also exhibits several resemblances to the skull of the modern Australian. Other skulls dug up in South Africa have also been described as exhibiting Australian characteristics. Sooner or later, therefore, fossil ancestral types of Australians will probably be found widely distributed in the tropics of the Old World.

In at least part of the first half of the Pleistocene period there must have been a direct connexion between Asia and North America in the region of Bering Straits. There may have been an isthmus of land, or there may have been only islands and continuous ice; but there was certainly a passage which allowed such mammals as the mammoth, bison, sheep, goat, elk, wapiti, reindeer and black bear to reach America for uthe first time. So far, there is no evidence that man accompanied these animals, and it may be that by then he had not yet reached the north-east corner of Asia. The woolly rhinoceros similarly never passed from Asia to America, although it was abundant and widely spread through the northern lands in the Old World. Its absence from America shows that in come cases there were impediments to emigration.

The earliest traces of Palæolithic man hitherto discovered in North America date back only to the later part of the Pleistocene period. Last year, Mr. J. Dorsch, when collecting for Mr. Childs Frick, found at Fairbanks, Alaska, some small endscrapers and conical cores, which Dr. N. C. Nelson recognised as identical with those which he had collected a few years before in large numbers in the Gobi desert. These seem to have been made by some of the latest Palæolithic men; and the only stone implements hitherto found in North America in direct association with the remains of typically Pleistocene mammals show that, when man arrived in that country, he had already learned the supreme art of trimming stone by pressureflaking. In pattern, indeed, his implements resemble those of Solutrean man in Europe, and even include the familiar Solutrean leaf-shaped blades, besides the characteristic spear points. They have lately been satisfactorily proved to be contemporaneous with extinct mammals of Pleistocene age in several localities, especially in New Mexico, Texas, Colorado, Nevada, and Nebraska.

Some of the typically Pleistocene mammals in the southern part of South America appear to have survived until comparatively recent times. 
Man was almost certainly associated with them, but nothing is known to distinguish this race from modern South American Indians. The supposed ancestors of the human family reported by Florentino Ameghino from the Tertiary rocks of Argentina are due to erroneous interpretation of the fossils, as already pointed out by Hrdlička and others.

The first fossilised remains of man in the South American continent were discovered exactly a hundred years ago in the caves of Minas Geraes, Brazil, by the Danish naturalist, Dr. Peter Wilhelm Lund, whose centenary has just been celebrated by the scientific men of Brazil in Lagoa Santa and Bello Horizonte. Under the direction of Prof. Anibal Mattos, three volumes have been published in Bello Horizonte, giving an account of Lund's researches, with a Portuguese translation of his scientific papers.

Some years ago the late Dr. Francisco P.
Moreno, Dr. Rudolf Hauthal and I, described the discovery of the dried skin and other remains of an extinct ground sloth (Neomylodon or Grypotherium), with fragments of other extinct mammals, in a cave in Last Hope Inlet, Patagonia. Here again, the presence of fires, cut and worked bone, and masses of hay cut for food for the ground sloth, led us to infer that man lived in Patagonia with the various Pleistocene mammals which are now extinct.

The races of men who eventually reached New Zealand and other remote islands were so far advanced in civilised life that they scarcely concern a palæontologist. They only interest him on account of the disturbance of the existing wild life and the extinctions which they have caused. The ethnologist now joins the human anatomist in attempting to explain the distribution of these people and to discover their relationships. They occupy a lowly sphere in the modern world.

\section{The Meaning of Probability}

\section{By Dr. Herbert Dingle}

$\mathrm{T}$ $\mathrm{HE}$ subject of probability originated in the consideration of actual but trivial problems. Its obvious attractions as a field for the exercise of mathematical ingenuity soon gave it a predominantly mathematical aspect, and in spite of its application to certain practical activities such as those of insurance companies, and its significance for statistical mechanics, it has until recently been treated as a branch of pure mathematics. Nevertheless, the word has a meaning in ordinary life among those who never concern themselves with mathematics. Such people have often to act without sufficient knowledge to predict with certainty the effect of their actions, and they do so in accordance with the 'probabilities' of the case. They do not calculate a numerical magnitude; they simply act in the way which they feel to be 'most likely' to produce the result they desire. Obviously, it is desirable that the precise scientific definition of probability should approximate as closely as possible to the pre-existing, indefinite conception which directs the majority of our actions. If it does not do so, it is not necessarily illegitimate mathematically or even physically, but it would then be better represented by another word.

Now in recent years probability has entered physics in a much more vital way than previously. This introduces another complication. In order to obtain physical credentials, concepts have now to satisfy certain conditions which mathematics does not impose, and, as we shall see, probability in its customary mathematical sense does not necessarily satisfy those conditions. We have therefore a threefold aspect of probability-an ordinary, everyday aspect, a mathematical aspect and a physical aspect; and unless hopeless confusion is to result, we must either use the word only to represent a conception which is satisfactory from all three aspects, or, alternatively, restrict our application of any narrower conception we may employ to those fields to which it legitimately belongs.

We must notice, however, that even when we have done our best to be precise, the question necessarily retains some vagueness-for two reasons. In the first place, when one wishes to convert an indefinite into a precise conception, one has obviously a certain latitude of choice, just as there was a certain latitude of choice in selecting a particular 'unknown soldier' to represent the general war hero. This affects our attempt to frame a mathematical or physical definition agreeing with our everyday use of the word. In the second place, the very idea of probability, however precise it is made, has an intrinsic vagueness, since, unless it has the value 1 or 0 (speaking in terms of the ordinary mathematical definition), it cannot be inconsistent with any single experiment made 